UDK 658.589:005.21:005.94

DOI: $10.15673 /$ fie.v10i2.963

\author{
Kalaman 0. \\ Ph.D., Associate Professor \\ Department of Management and Logistics \\ E-mail: kalaman.olga@gmail.com \\ Volodina 0. \\ Assistant \\ Department of Foreigh Languages \\ E-mail: completeness7@mail.ru \\ Mandrikin D. \\ Undergraduate \\ Department of Management and Logistics \\ Odessa National Academy of Food Technologies \\ Kanatna str., 112, Odesa, Ukraine, 65039 \\ E-mail: currrsor@gmail.com
}

\title{
INNOVATIVE DEVELOPMENT STRATEGY FORMATION OF THE MODERN ENTERPRISE
}

The article analyzes the concept of innovation and innovation development. Separately the importance of innovative development for the formation of the strategy of a modern enterprise has been shown. The analysis of world innovative processes and their influence on the economy of the country has been carried out. The relationship between innovation development and state expenditures on the research work has been shown. It is shown which models of an innovation policy are used in different countries of the world. The change of index of the global index of innovations in the world has been analyzed. The importance of internationalization of science and scientific and technological progress for the development of the modern world economy has been emphasized. The problems that exist today in Ukraine in the field of science and complicate innovation activity have been highlighted. The relevance of the development of the strategic management theory has been shown. The trend for activity of modern enterprises has been highlighted.

Key words: knowledge economy, innovative economy, innovations, innovation system, world economy, formation of development strategy, global index of innovations, theory of strategic management.

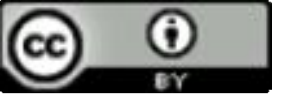

This work is licensed under a Creative Commons Attribution 4.0 International License http://creativecommons.org/licenses/by/4.0/
Statement of the problem and its connection with important scientific and practical tasks. Development of innovations and innovation activity in the $21^{\text {st }}$ century. is a leading, priority area for the economic policy of all countries of the world, along with such fundamental issues as the quality of education, the development of a variety of traditional as well as non-traditional types of energy. It is obvious that the rise of the economy, the transition to qualitatively new production bases can not happen without innovation development, the development of new technologies, the introduction of them into the real production. In this process, the innovation activity serves as an intermediary between scientific and research organizations, enterprises and end users. At the same time, the processes which have proceeded since the end of the twentieth century. in most countries of the world and received the brightest manifestation in the countries of North America and Europe, stipulated the main directions in the development of the world economy. The world scientific community, observers, analysts called this trend globalization, which is the central trend in the development of the world economy and the world community.

The analysis of the latest publications on the problem. In Ukraine, research on innovation development issues of the enterprise was carried out by the lead- ing scientists, including: T.V. Grin'ko [1], O.S. Efremova [2], AS Zakharchenkova [3], O.V. Kornukh [4], V.A. Pavlova [5; 6] and others.

Forming of the aims of the research. However, it is important to note that in the second half of the 90-s of the twentieth century, the related terms: "knowledge economy", "new economy", "innovative economy", and also the derivative - "innovation system" appeared and accupied a special place in economic and other scientific literature. Nevertheless, in practice, these terms don't denote a new reality, but only its origin, because, according to the experts, it will take 15-25 years for an economy to appear in the full sense. Therefore, the issues related to the formation of a strategy for innovation development of a modern enterprise remain insufficiently considered. This is what made the choice of the research direction for this article.

Giving an account of the main results and their substantiation. The new economic paradigm, the transition to which is being implemented now, sees growth of non-material resources as the main, general factors, as it happened during the previous periods of development, and scientific and technological progress, in the broad interpretation of this concept, sees knowledge as the main factors of economic growth. The distinctive feature of the innovative economy is the rapid 
development of the spheres of intangible assets (resources), and the non-material sphere of the economic activity. The knowledge and other non-material resources become the main priorities of business practice. It is in the predominance of intangible resources that we see the essence of the economic innovation development.

As an assumption, there are broad opportunities for the new spheres of the world economy such as genetic engineering, telecommunication and other information technologies, the use of atomic and other types of energy and others. We can not forget about such a powerful engine of the development of advanced technologies as a significant limitation of all traditional resources due to their rapid use and growth of the population of the Earth. OECD experts note that in the 1990-s of the twentieth century the member countries of this organization were distinguished by a higher level of investment in knowledge, expressed in R \& D expenditure, higher education, computer and information technology, and these investments in terms of growth passed ahead the investment in fixed assets [7].

The main world trend of the beginning of the $21^{\text {st }}$ century in the innovative activities of developed and some developing countries, is aimed at the emergence of energy-saving developments, as well as highperformance technologies, the production of goods and services based on them, which are characterized by high technical, technological and consumer properties, and sometimes by completely new products that do not have analogues and form new flows of a consumer demand (so-called "world production").
The countries of Western Europe, North America (USA, Canada), Southeast Asia, and Japan use national innovation systems (NIS) as a basis for national growth and development. Such systems represent a certain nonfixed set of organizations and enterprises in the private and public spheres that are engaged in the innovation activity on a state scale, and sometimes go beyond it, while interacting with each other [8].

It is interesting to note that since 2007 the global index of innovations has been defined, which characterizes the innovative development of the countries of the world, which are at different levels of economic development, by 80 different variables [9]. The index is calculated on the basis of the weighed sum of estimates of two groups of indicators: available resources and conditions for implementation (Innovation Input), namely: institutes, human capital and research, infrastructure, development of the domestic market, business development and achieved innovative results (Innovation Output): development of technologies and knowledge economy, results of creative activity. By comparing indicators of the index of innovation and GDP per capita, there are three groups of states: the first group - "leaders of innovations" - highincome countries; the second group - "studentsinnovators" - middle income countries; the third group "lagging behind" - countries that differ by the weakness of innovation systems. It can be confirmed that the index, which is determined by the ratio of costs and effect, allows us to objectively assess the effectiveness of efforts for the development of innovations in a particular country under study [10] (Table 1).

Table 1

Global Index of Innovations in 2012 and 2017 [10]

\begin{tabular}{|c|c|c|c|c|c|}
\hline \multicolumn{2}{|c|}{2012} & \multicolumn{3}{c|}{2017} & index \\
\hline rating & country & index & rating & country & 67,69 \\
\hline 1 & Switzerland & 68,2 & 1 & Switzerland & 63,82 \\
\hline 2 & Sweden & 64,8 & 2 & Sweden & 63,36 \\
\hline 3 & Singapore & 63,5 & 3 & Netherlands & 61,4 \\
\hline 4 & Finland & 61,8 & 4 & USA & 60,89 \\
\hline 5 & United Kingdom & 61,2 & 5 & United Kingdom & 37,62 \\
\hline 63 & Ukraine & 36,1 & 50 & Ukraine & 15,64 \\
\hline 141 & Sudan & 16,8 & 127 & Yemen & \\
\hline
\end{tabular}

As can be seen from Table. 1, in the global economy, the TOP-5 of developed countries remain practically unchanged, but it is likely that competition for the market segments between them is quite significant, which forces to constantly improve the economy at the expense of innovations. Ukraine is in the midst of the studied countries. It can be attributed to a group of "novice students" as an average income country, demonstrating the growth of innovative achievements as a result of improving institutional infrastructure and integration with global markets. This is not enough to declare competitiveness on a par with developed countries, and therefore increasing competition in the world market forces domestic business structures to apply innovative approaches to ensure their own development [1; 4]. Important in this sense is the study of the status and possibilities of reaching the level of the countries oriented towards innovation.

Different countries use different models of innovation policy, in which their national peculiarities and orientations are characteristic. Japanese and American models of such a policy are distinquished. A distinctive feature of the American model is the most complete, compared with models of other countries, autonomy of entrepreneurial activity. The Landmarks of economic development are special areas, the main among them the military technology, the technological priority of which is provided, including the investment of public funds. The Japanese model, which also relies on the technological priority, develops technologies in the selected specific areas, such as the technology of building large tankers, followed by technologies and developments for the production of robots.That is, the technological benefits 
that are expected and expected to be achieved are determined at the state level. Their development is stimulated in order to use the technologies obtained in all sectors of the national economy.

In the recent decades, the importance of measures for direct and indirect stimulation of innovations in the state has increased. For this purpose, such measures as tax breaks, targeted support for small and mediumsized businesses of innovation orientation, the formation of innovation infrastructure, support of relevant institutions, as well as the transfer of technologies to industry by the public sector economy are used. These limits have allowed many industrial countries (the US and the EU) to set and fulfill such a strategic objective as an increase in the share of total R \& D expenditures in GDP to 3\%.

Some countries (Austria, Spain, Ireland, Canada, Australia, Portugal, France, the Netherlands, Korea, Japan, USA) encourage corporate investments in R \& D using financial instruments such as discounts, tax breaks, while others (Germany, Iceland, New Zealand, Denmark, Norway, Belgium, Sweden, Switzerland, Finland) apply general rules for the interpretation of such investments.

In the UK, a new law has been introduced since 2000, which allows small and medium-sized businesses to deduct the costs of R \& D from the tax base, and two years later (in 2002), this approach was partially extended to large national industry companies.

There are interstate differences in national priorities, especially in the applied and fundamental research. The United States focuses on medical and military-applied research, many OECD countries favor engineering and physical sciences. Japan prefers energyrelated developments and studies, France - space sector, Canada - agriculture, Germany, Italy, South Korea - industrial technologies.

Along with globalization, the internationalization of scientific, scientific and technological, technological, as well as production activities has become a marked tendency of the economic development. Thus, in Great Britain and Canada, financing of R\&D of industrial sphere by foreign investors was noted up to $20 \%$ of the total cost [7].

Based on the foregoing, one can distinguish the state innovation policy of the successful developed countries - it is the maintenance of VAT, ensuring the conditions under which the national economy could develop harmoniously and would be attractive to foreign investors.

At the same time, there are problems in Ukraine that complicate the innovative activities of the national business. First of all, this is not a high enough level of labor productivity, shortage of skilled labor resources, low quality of the produced products, etc. Many enterprises, trying to solve these problems, come to the conclusion that it is necessary to purchase modern equipment and technologies abroad, without seeing the real possibility of attracting the national technological resource.

Over the last decade, the number of design bureaus (which, first of all, determine the pace and level of NTP) decreased by more than three times, from 930 to 274 units. There is even more oppressive picture in the project organizations, their number was reduced by 7.3 times (now there are 77 design bureaus in the country). Nevertheless, it is evident that the successful development of the real sector of the industry requires sufficient scientific, technical and technological support.

The physical deterioration of the existing fixed assets in the country exceeded $50 \%$ (for the equipment and machinery - about $61 \%$ ). The processing industry and other industries of Ukraine can not provide the competitiveness of products produced on the external and internal markets without significant renewal of fixed assets with the involvement of the modern technological base.

One can not but mention the extremely insufficient investments in the innovation activity. According to the statistics, totally inefficient volumes of state funding were found to be $3.6 \%$, based on the data of the State Statistics Committee and $2.4 \%$ of the IEPP. More than $90 \%$, according to IEPP, did not receive public funding at all. Small enterprises receiving public funding noted that its share is small (15\% on average on a sample basis) [11]. Foreign investments in the innovation activity is less than $1 \%$, and budgets of different levels offer a figure of $2.6 \%$. The situation gets complicated by a system of taxation that is not well developed and does not work to stimulate innovation activity, in addition, the rates of loans are too high for medium and small businesses.

Since 1991 there has been a reduction in the financing of the scientific research. By comparing the amount of science expenditure related to GDP, in 1990 these costs amounted to $2.03 \%$, and in 2013 they declined to $0.56 \%$ [5]. The measures for privatization in Ukraine of most industry research institutes after the collapse of the USSR did not bring the expected effect, as large enterprises practically abandoned the principle of ordering for the research. The state had to take on the support of the largest research institutes that carry out applied developments. Such research institutes have been given special status - they have become state scientific centers (DNCs). As a result of transformations, the innovative enterprise of small businesses has undergone an annual reduction after 1996 [6].

Despite the fact that the state did not leave attempts to support innovation activity, the statistics clearly shows that in the last decade of the twentieth century. The index of the number of new, mastered in the country for the first time, technologies and techniques, decreased by three times compared with the previous decade. Limiting of material and technical capabilities has played a major negative role in this. The relatively positive result can be called a partial reorientation of enterprises, aimed at product upgrades [12].

The after-restructuring period was characterized by an even lower level of innovation activity of enterprises.

There is a whole set of reasons that stimulate an enterprise to innovative activities. According to IEPP, about $73 \%$ of enterprises and organizations are engaged in the innovation activities in order to remedy the financial situation. Storage or even increase in the market share or desire to find new markets is encouraged by $68 \%$ and $60 \%$ enterprises respectively, this reason seems to be 
the second (important) incentive to stimulate innovation [11].

Statistics also offers a pattern that can be called a tendency to increase the innovation activity observed at enterprises. This pattern is obvious and is related to the financial resources of organizations and enterprises that can be disconnected from the main production without visible damage. Unfortunately, it should be noted that there is a fairly high share of non-innovative enterprises, accounting for almost $40 \%$.

The analysis of costs which was carried out also reveals an accompanying tendency that the prevailing share of funds is invested in the new equipment. But these costs can rather be attributed to fixed capital investments, than in innovations. The structure of the purchased equipment, shows that the largest share of the costs is directed to the purchase of individual installations, while the number of acquired technological lines is much lower. Thus, there is a conclusion about the discrepancy with the set priorities: worn-out technique is subject to the upgrade, and the possibility of transfer to a new technological process remains unused [13].

However, in the developed countries, the process of innovation development has long evolved into the urgent need and the norm of functioning of the business, an essential element of economic development and a key factor of competitiveness. The participation in such a process, the use of motive stimulating force takes place within a system of conscious and thoughtful stages. Moreover, enterprises are engaged not in separate innovations, but in raising innovation activity on a strategic basis. The innovative activity of the subject of the economy is amenable to strategic management as a result of its duration, the need for designing and evaluating new ideas and inventions, conceptual reviews, conducting research and development work, etc.

The theory of the strategic management, especially the innovation development, represents a relatively recent trend in economic science and is formalized in the certain system in the second half of the twentieth century. Its appearance is caused by the practical need for completely different methods and methods aimed at making appropriate managerial decisions in connection with the repeatedly growing uncertainty of new business conditions, the inappropriateness of old methods of solving problems in this changing reality and the volatility of economic dynamics [14].

These new conditions forced the big business of the developed countries back in the second half of the twentieth century. to deviate from the previous extrapolation method of planning, which consists in the fact that a set of indicators of mainly financial, past periods served as the basis for the development of strategic decisions [14]. The method provided for the introduction of a number of corrections for the coefficients of the use of past years indicators. The new, situational approach considers an enterprise as an open system, and the success of the system determines the system's ability to adapt to the factors of the environment. World standards for quality management (ISO 9000, 1987) have been developed on this basis.
The basic principles of the system are as follows:

- orientation towards the consumer;

- leadership of the head (the provision of one goal in the team, is included in the duties of the head coordination of activities of the enterprise);

- involvement of employees (this allows to employ the full potential of the employees);

- process approach (guarantees maximum effectiveness if the activity is considered as a chain of interconnected processes);

- a systematic approach (complements the previous one and obliges to consider interrelated processes as a system);

- constant improvement (unchanged goal);

- decisions are made only on the basis of facts (data and information);

- mutually beneficial relations with all suppliers, the interdependence of all organizations in the chain of production processes of the final products.

Thus, the prerequisites for an effective strategic development of innovation activity and industry activity have historically developed [15].

The modern period is characterized by a shift in the significance of the factors affecting the consumer value of the goods, the transition from predominantly quantitative factors (quality, price, technology) to qualitative (social recognition of the brand, need for it, emotional justification, urgent need, etc.).

Based on the foregoing, one can note the emergence of new directions of innovation at present. Previously, a number of priority types of such activities included: conducting research and development work on the idea of innovations, laboratory research and preparation of laboratory samples of products, copies of new techniques, structures or products; selection of the necessary raw materials and materials for production of products; development of all details of the technological process; development, manufacturing, testing and implementation of samples of the necessary equipment for the manufacture of new products, etc., now other areas are becoming important:

- teaching, training, retraining of the staff, the most active tool for the implementation of innovative projects and any programs;

- development and introduction of the latest organizational and managerial decisions for sustainable growth of competitiveness of the enterprise and products, constant growth of brands positions;

- development, research, acquisition of necessary information resources, use of the latest information technologies and provision of operational planning abilities, realization of production and economic activity and control over it;

- formation of the strategy that takes into account the threats and opportunities (strengths and weaknesses) of the enterprise in the intensified competition;

- licensing, acquisition of inventions (knowhow), mandatory transition to world quality standards;

- organizing and conducting events that activate the activities of marketing services in order to promote 
innovations, enhance the business image of an organization or enterprise.

The above mentioned directions identified the main problems of developing an effective development strategy on the innovative basis:

- difficulties encountered in reorientation of decision-makers to the directions adopted for the pursuit of innovation activities;

- shortage of the trained personnel who could participate in the development of the strategy;

- lack of experience with the successful implementation of the developed strategies aimed at innovative development, due to the lack of such experience;

- deficiencies in the definition of so-called "key competencies" that could serve as the basis for innovation activity, stimulation of innovation potential;

- shortcomings of analogous or similar, already described and implemented business processes and effective organizational structure, which led to the success at other enterprises, that is, the lack of consensus examples;

- the need to reorient the client-oriented approach, which requires clear purposes not only for high productivity, but also a constant correction of plans to study "their" client [16];

- change of the internal essence of the innovative development of the enterprise from extensive to intensive, one which could lead the company to a higher, or even world level of competitiveness.

Unfortunately, the period of larger reforms of the 1990s caused a "directorship revolution", during which the interests of managers were higher than the interests of enterprises, so the decisions were made without the necessary share of responsibility. In addition, the restructuring processes have caused the emergence of the managers who are not fully competent in matters of management [17].

Today's approach is to realize the commercial activity and profit, and all enterprises use their own strategy for this. Therefore, for the production of competitive innovation products, the conquest of long-lasting stable competitive positions in the world market, to avoid the excessive-sale of natural resources of the developed countries, we consider that the relevance of raising the level of innovation activity of specific enterprises, their functioning within the framework of the state innovation strategy, creation of internal and accounting of external conditions for the growth of innovative activity of the entrepreneurial sector? Have significantly increased.

The current low level of competitiveness of domestic producers' products can be explained by the use of significantly outdated technologies, backward technologies, lack of investment resources, depreciated innovation infrastructure, and the absence of a solid state policy aimed at stimulating and supporting of enterprise innovation activity.

Conclusions and prospects of the further investigations. The conducted analysis allows us to conclude that both in the internal and external environment of functioning of modern enterprises there are certain contradictions and obstacles that complicate the development of the innovative processes. Moreover, the very specificity of the processes, both the realization and the implementation of such innovative strategies, to some extent determines the results obtained. Nevertheless, we believe that some degree of formalization of these processes is possible. To do this, it is necessary to build a system for developing an integral development strategy, taking into account innovative activity, within which the sequence of stages of formation and implementation of the strategy will be determined.

Summing up, we get the following conclusions:

First, the development of a strategy for the development of a particular modern enterprise, which provides an innovative basis, determines all subsequent actions of incentives for future innovation activity of the enterprise. It is a very urgent goal for the successful development of production, and at all levels - from a specific enterprise to the state level, since the need to build a so-called "knowledge economy", which determines the transition to the next technological structure and extraction from the status of the raw material appendage, is very large. At the heart of such an economy there is an innovation activity, the pace of which determines the degree of innovation activity of all sectors and enterprises of the country.

Secondly, it should be noted the complexity of the situation of the enterprises of our state, according to the objective historical reasons, which were not engaged in the construction of innovative strategies, as well as the stimulation of their productions. It is known that the planning of the creation, as well as the introduction of the new types of technology and new technologies, the carrying out of fundamental research work were determined by the state authorities and represented part of the overall state strategy. The question of commercialization of the mentioned innovation activity has never occurred.

Thirdly, there are no sufficiently clear mechanisms for a reliable quantitative assessment of the effectiveness of the received development strategy, which provides an innovative basis.

Fourthly, managers of certain modern enterprises have insufficient training and competence to solve such issues.

Fifthly, the formation of an effective strategy, as well as its implementation, requires the creation of a well thought-out integrated system that takes into account the influence of all possible factors on the activity of the innovation activity. It is also necessary to formalize actions aimed at developing and implementing the innovation strategy, which will be accompanied by adequate mechanisms for quantification. Taking into account all of the above mentioned will allow modern enterprises to develop their "active" strategy of the innovation development. 


\section{References}

1. Grinko, T. V. (2011). Osnovyi upravleniya adaptivnyim innovatsionnyim razvitiem predpriyatiya. Problemyi Ekonomiki, (3). Retrieved from https://vdocuments.mx/-5750a9aa1a28abcf0cd20188.html

2. Yefremov, O. S. (2012). Vzaiemozv'iazok osnovnykh elementiv stratehii innovatsiinoho rozvytku pid$\begin{array}{llllll}\text { pryiemstva. Marketynh } & I & \text { Menedzhment } & \text { Innovatsii, (1), } & \text { 228-233. } & \text { Retrieved from }\end{array}$ http://mmi.fem.sumdu.edu.ua/journals/2012/1/228-233

3. Zaharchenkov, A. S. (2012). Problemyi innovatsionnogo razvitiya promyishlennyih predpriyatiy v Ukraine i formirovanie strategiy innovatsionnyih preobrazovaniy. Biznes Inform, (2). Retrieved from http://www.businessinform.net/export_pdf/business-inform-2012-2_0-pages-57_61.pdf

4. Kornukh, O. V. (2013). Stratehichne upravlinnia innovatsiinym rozvytkom pidpryiemstva. Efektyvna Ekonomika, (12). Retrieved from http://www.economy.nayka.com.ua/?op=1\&z=2607

5. Pavlova, V. A., \& Tatarinov, V. V. (2012). Aktyvizatsiia innovatsiinoi diialnosti pidpryiemstva za rakhunok poshuku novykh dzherel finansuvannia. In Suchasni kontseptsii, peredumovy ta perspektyvy rozvytku pidpryiemstv Ukrainy [upravlinskyi aspekt]. Donetsk: Vydavnytstvo LANDON-KhKhI.

6. Pavlova, V. A., Tatarinov, V. V., \& Zhukova, A. H. (2013). Innovatsiinyi rozvytok pidpryiemstva: Orhanizatsiia, otsinka potentsialu, efektyvnist. Dnipropetrovsk: Dnipropetrovskyi universytet imeni Alfreda Nobelia.

7. Nonaka, I., \& Takeuchi, H. The Knowledge-Creating Company. Retrieved from https://www.strategybusiness.com/article/8592?gko=5a1e5.

8. Kornyishova, E., \& Motyishina, M. (2007). Opredelenie napravleniy v razvitii personala na osnove vyideleniya prioritetnyih biznes-protsessov. Upravlenie Personalom, (8), 37-45.

9. Reyting razvitiya innovatsiy $\mathrm{v}$ stranah mira. Retrieved from http://gtmarket.ru/ratings/global-innovationindex

10. Orlova, V. M. (2015). Stratehiia innovatsiinoho rozvytku pidpryiemstva. Ekonomichnyi Nobelivskyi Vis$n y k,(1(8)), 79-85$. Retrieved from http://econforum.duan.edu.ua/images/stories/Files/2015/12.pdf

11. Zhigun, L. A., Razumev, M. L., \& Tsovbun, O. A. (2006). Onto- i gnoseologicheskie osnovyi razrabotki strategii razvitiya torgovli. Vestnik TGEU, (4), 29-38.

12. Koh, R. (2003). Izmeneniya strategii v XXI veke. Retrieved from http://www.management.com.ua/strategy/str059.html DANA.

13. Lyukshinov, A. N. (2008). Strategicheskiy menedzhment: Uchebnoe posobie dlya vuzov. M.: YuNITI-

14. Shevchenko, S. Yu. (1998). Innovatsionnoe razvitie i konkurentosposobnost: Metodologiya obosnovaniya strategicheskih resheniy. SPb.: Izd-vo SPbGUEF.

15. Shichkov, N. A. (Ed.). (2010). Razrabotka, vnedrenie na predpriyatii i podgotovka $k$ sertifikatsii Sistemyi Menedzhmenta Kachestva na osnove MS ISO 9001: 2000 (2-e izd. ed.). SPb.: SPbLTA.

16. Breddik, U. (1997). Menedzhment v organizatsii. M.: «INFRA-M».

17. Fathutdinov, R. A. (2003). Innovatsionnyiy menedzhment. SPb.: Piter.

Received 1 March 2018

Approved 15 March 2018

Available in Internet 7.07.2018

Каламан О.Б.

кандидат экономических наук, доцент кафедра менеджмента и логистики E-mail:kalaman.olga@gmail.com

\section{Володина Е.П.} ассистент

кафедра иностранных языков E-mail: completeness7@mail.ru

\section{Мандрыкин Д.В.} магистрант

кафедра менеджмента и логистики

Одесская национальная академия пищевых технологий

ул. Канатная, 112, г. Одесса, Украина, 65039

E-mail: currrsor@gmail.com

\section{ФОРМИРОВАНИЕ СТРАТЕГИИ ИННОВАЦИОННОГО РАЗВИТИЯ СОВРЕМЕННОГО ПРЕДПРИЯТИЯ}

Сегодняшнее развитие экономики страны отличается недостаточно устойчивым состоянием украинских предприятий. В таких условиях главным способом выхода из сложившейся ситуации является реформирование предприятий, то есть их модернизация с помощью инновационного развития. Одной из основных перспективных направлений является фрормирование стратегии инновацион- 
ного развития.

Реорганизация предприятий, реализуемая в передовых развитых государствах, таких как Германия, Япония, США и прочих, является обязательным планируемым, непрерывным и постоянным процессом в системе управляемого развития. Реорганизация современных украинских предприятий сталкивается с рядом проблем, вызванных нестабильностью среды, то есть проблемами трансформационного периода. Система рыночных отношений в такие моменты не сбалансирована и управления ею не отрегулировано. Предприятия ориентируются только на выживание и всеми силами борются за беспрерывность функционирования в сложных условиях.

Неопределенность среды, в которой приходится работать современным предприятиям, большое разнообразие вариантов использования собственных и заемных ресурсов, обусловливают возможности и растущую интенсивность контактов между экономическими субъектами. Именно в такие моменты на первый план выходит проблема эффективного применения формирования стратегии инновационного развития в качестве основного инструмента по реализации стратегии успеха предприятия.

Поэтому целесообразно было раскрыть тенденцию развития отечественной экономики, в том числе промышленности, показать, что подавляющее доля средств вкладывается в новое оборудование, то есть технику, а возможности перехода на новый технологический уклад остаются неиспользованными, в то время как процесс, направленный на инновационное развитие, требует повышения инновационной активности на стратегическом уровне.

Также рассмотрены условия формирования предприятием стратегии развития с использованием инновационной основы, показана необходимость учитывать ряд факторов внутренней и внешней среды, которые так или иначе влияют на инновационную деятельность и активность. Показано, что разработка стратегии, которая предусматривает инновационную основу, составляет ее идейноцелевую базу и является актуальной целью для успешного развития промышленности страны, построения «экономики знаний» и лишения страны унизительного статуса «сырьевого придатка».

Ключевые слова: экономика знаний, инновационная экономика, инновации, инновационная система, мировая экономика, формирование стратегии развития, глобальный индекс инноваций.

Каламан О.Б.

кандидат економічних наук, доцент кафедра менеджменту і логістики E-mail: kalaman.olga@gmail.com

\section{Володіна О.П.} асистент

кафедра іноземних мов

E-mail: completeness7@mail.ru

Мандрикін Д.В.

магістрант

кафедра менеджменту і логістики

Одеська національна академія харчових технологій

вул. Канатна, 112, м. Одеса, Україна, 65039

E-mail: currrsor@gmail.com

\section{ФОРМУВАННЯ СТРАТЕГІЇ ІННОВАЦІЙНОГО РОЗВИТКУ СУЧАСНОГО ПІДПРИЕМСТВА}

Сьогодення розвитку економіки нашої країни відрізняється недостатньо стійким станом українських підприємств. В таких умовах головним способом виходу з подібної ситуації є реформування підприємств, або їх модернізація за допомогою заходів інноваційного розвитку. Однією з основних рушійних сил на цьому шляху є формуванням стратегії інноваційного розвитку.

Реорганізація підприємств, що проводиться провідними розвиненими державами, такими як Німеччина, Японія, США та ін., є обов'язковий планований, безперервний і постійний процес в системі керованого розвитку. Реорганізація сучасних українських підприємств стикається з низкою проблем, викликаних нестабільністю середовища, тобто проблемами трансформаційного періоду. Система ринкових відносин в такі моменти не збалансована та управління нею не відрегульовано. Підприємства орієнтуються тільки на виживання і всіма силами борються за продовження діяльності в складних умовах.

Невизначеність середовища, в якому доводиться функціонувати сучасним підприємствам, велика різноманітність варіантів використання своїх і запозичених ресурсів, зумовлюють можливості і зростаючу інтенсивність контактів економічних суб'єктів. Саме в такі моменти на першому плані постає проблема ефективного застосування формуванням стратегії інноваційного розвитку в якості основного інструменту з реалізації стратегії успіху підприємств.

Тому доцільно було розкрити тенденцію розвитку вітчизняної економіки, в тому числі проми- 
словості, показати, що переважаюча частка коштів вкладається в нове обладнання, тобто техніку, а можливості переходу на новий технологічний уклад залишаються невикористаними, в той час як процес, спрямований на інноваційний розвиток, вимагає підвищення інноваційної активності на стратегічній основі.

Також розглянуто умови формування підприємством стратегії розвитку з використанням інноваційної основи, показана необхідність враховувати ряд фракторів внутрішнього і зовнішнього середовища, які так чи інакше впливають на інноваційну діяльність та активність. Показано, що розробка стратегії, яка передбачає інноваційну основу, складає її ідейно-цільову базу і є актуальною метою для успішного розвитку промисловості країни, побудови «економіки знань» та позбавлення країни принижуючого статусу «сировинного придатку».

Ключові слова: економіка знань, інноваційна економіка, інновації, інноваційна система, світова економіка, формування стратегії розвитку, глобальний індекс інновацій.

\section{Література}

1. Гринько Т.В. Основы управления адаптивным инновационным развитием предприятия [Электронный pecypc] / Т.В. Гринько // Проблемы экономики. - 2011. - Вып. № 3. - Режим доступа: https://vdocuments.mx/-5750a9aa1a28abcf0cd20188.html

2. Сфремов О.С. Взаємозв'язок основних елементів стратегії інноваційного розвитку підприємства [Електронний ресурс] / О.С. Єфремов // Маркетинг і менеджмент інновацій. - 2012. - № 1. - С. 228-233. - Режим доступу: http://mmi.fem.sumdu.edu.ua/journals/2012/1/228-233

3. Захарченков А.С. Проблемы инновационного развития промышленных предприятий в Украине и формирование стратегий инновационных преобразований [Электронный ресурс] / А.С. Захарченков // Бизнес Информ. - 2012. - Вып. № 2. - Режим доступа: http://www.business-inform.net/export_pdf/business-inform-20122_0-pages-57_61.pdf

4. Корнух О.В. Стратегічне управління інноваційним розвитком підприємства [Електронний ресурс] / О.В. Корнух // Ефективна економіка. - $2013 . \quad$ - № $12 . \quad$ - Режим доступу: http://www.economy.nayka.com.ua/?op=1\&z=2607

5. Павлова В.А. Активізація інноваційної діяльності підприємства за рахунок пошуку нових джерел фінансування // Сучасні концепції, передумови та перспективи розвитку підприємств України [управлінський аспект]: [колективна монографія] / В.А. Павлова, В.В. Татарінов. - Донецьк: Видавництво ЛАНДОН-ХХІ, 2012. $-344 \mathrm{c}$.

6. Павлова В.А. Інноваційний розвиток підприємства: організація, оцінка потенціалу, ефективність: [монографія] / В.А. Павлова, В.В. Татарінов, А.Г. Жукова. - Дніпропетровськ: Дніпропетровський університет імені Альфреда Нобеля, 2013. - 200 с.

7. Nonaka I. The Knowledge-Creating Company / I. Nonaka, H. Takeuchi //strategy-business. - [Электронный ресурс]. - Режим доступа: https://www.strategy-business.com/article/8592?gko=5a1e5.

8. Корнышова Е. Определение направлений в развитии персонала на основе выделения приоритетных бизнес-процессов / Е.Корнышова, М.Мотышина // Управление персоналом. - 2007. - № 8. - С.37 - 45.

9. Рейтинг развития инноваций в странах мира [Электронный ресурс]. - Режим доступа: http://gtmarket.ru/ratings/global-innovation-index

10. Орлова В. М. Стратегія інноваційного розвитку підприємства [Електронний ресурс] / В. М. Орлова // Економічний нобелівський вісник. - 2015. - № 1(8). С. 79 - 85. - Режим доступу до ресурсу: http://econforum.duan.edu.ua/images/stories/Files/2015/12.pdf

11. Жигун Л.А. Онто- и гносеологические основы разработки стратегии развития торговли / Л.А.Жигун, М.Л.Разумев, О.А.Цовбун // Вестник ТГЭУ. - 2006. - № 4. - С.29 - 38.

12. Кох Р. Изменения стратегии в XXI веке: глава из кн. Стратегия. Как создавать и использовать эффективную стратегию [Электронный ресурс] / Р.Кох. - Режим доступа: http://www.management.com.ua/strategy/str059.html

13. Люкшинов А.Н. Стратегический менеджмент: учебное пособие для вузов/ А.Н.Люкшинов. - М.: ЮНИТИ-ДАНА, 2008. - 375с

14. Шевченко С.Ю. Инновационное развитие и конкурентоспособность: методология обоснования стратегических решений/С.Ю.Шевченко. - СПб.: Изд-во СПбГУЭФ, 1998. - 139с.

15. Разработка, внедрение на предприятии и подготовка к сертификации Системы Менеджмента Качества на основе МС ИСО 9001: 2000: [метод. пособие] / под ред. Н.А. Шичкова. - [2-е изд.]. - СПб.: СПбЛТА, 2010. - 55c.

16. Брэддик У. Менеджмент в организации / У.Брэддик. - М.: «ИНФРА-М», 1997. - 334с.

17. Фатхутдинов Р.А. Инновационный менеджмент / Р.А.Фатхутдинов. - СПб.: Питер, 2003. - 491с.

Стаття надійшла 1.03.2018

Стаття прийнята до друку 15.03.2018

Доступно в мережі Internet 7.07.2018 